\title{
More examples of breakdown the 1:1 partner specificity between figs and fig wasps
}

\author{
Hui Yu ${ }^{1,2,3^{*}} \mathbb{D}$, Yaolin Liao ${ }^{1}$, Yufen Cheng ${ }^{1}$, Yongxia Jia ${ }^{1}$ and Stephen G. Compton ${ }^{4}$
}

\begin{abstract}
Background: The obligate mutualism between fig trees (Ficus, Moraceae) and pollinating fig wasps (Agaonidae) is a model system for studying co-evolution due to its perceived extreme specificity, but recent studies have reported a number of examples of trees pollinated by more than one fig wasp or sharing pollinators with other trees. This will make the potential of pollen flow between species and hybridization more likely though only few fig hybrids in nature have been found. We reared pollinator fig wasps from figs of 13 Chinese fig tree species and established their identity using genetic methods in order to investigate the extent to which they were supporting more than one species of pollinator (co-pollinator).

Results: Our results showed (1) pollinator sharing was frequent among closely-related dioecious species (where pollinator offspring and seeds develop on different trees); (2) that where two pollinator species were developing in figs of one host species there was usually one fig wasp with prominent rate than the other. An exception was F. triloba, where its two pollinators were equally abundant; (3) the extent of co-pollinator within one fig species is related to the dispersal ability of them which is stronger in dioecious figs, especially in small species.

Conclusions: Our results gave more examples to the breakdown of extreme specificity, which suggest that host expansion events where pollinators reproduce in figs other than those of their usual hosts are not uncommon among fig wasps associated with dioecious hosts. Because closely related trees typically have closely related pollinators that have a very similar appearance, the extent of pollinator-sharing has probably been underestimated. Any pollinators that enter female figs carrying heterospecific pollen could potentially generate hybrid seed, and the extent of hybridization and its significance may also have been underestimated.
\end{abstract}

Keywords: Agaonidae, Co-speciation, Ficus, Fig wasps, Host specificity, Hybrids

\section{Background}

Ficus (Moraceae) is one of the most species-rich genera of woody plants in tropical and subtropical regions of the world (Harrison 2005), with more than 800 described species of free-standing trees, shrubs, climbers, and (hemi-)epiphytes (Corner 1965; Berg 1989, 1990). Figs are defined by their unique enclosed inflorescences (the fig or syconium) and their associated pollination system which

\footnotetext{
*Correspondence: yuhui@scib.ac.cn

${ }^{1}$ Plant Resources Conservation and Sustainable Utilization, South China Botanical Garden, The Chinese Academy of Sciences, Guangzhou 510650, China

Full list of author information is available at the end of the article
}

requires entry into figs by highly-specialized fig wasps (Hymenoptera, Agaonidae). Pollinator fig wasps enter the figs to lay their eggs inside the ovules of the tiny flowers they contain. For a long period it was believed that each species of fig tree supported its own unique species of pollinator fig wasp, which was associated with no other Ficus species (Ramírez 1970; Wiebes 1979). When atypical pollinators were detected within figs it was assumed that these were rare mistakes that resulted in the death of the pollinators without the production of their offspring or generation of fertile seeds (Compton 1990; Ware and Compton 1992) though there was an exception of hybrids by artificial pollination (Condit 1950). More recently, it has been realized that more than one species of pollinator 
may be associated routinely with a single species of Ficus, and that widespread fig tree species can support multiple pollinators in different places but with co-occurrence in contact zones (Sun et al. 2011; Bain et al. 2016; Chen et al. 2012; Yu et al. 2019), or replace each other but with more extended overlap of distributions (Rodriguez et al. 2017), or with 2 or more pollinators over substantial parts of the range Molbo et al. 2003; Haine et al. 2006; Darwell et al. 2014). There are also examples of pollinator sharing, where two or more Ficus species are routinely hosts for a single species of fig wasp (Lopez-Vaamonde et al. 2001; Cornille et al. 2012; Wachi et al. 2016; Wang et al. 2016). The one-to-one relationship that was originally envisaged is now realized to have been the result of the small number of host records available from each Ficus species, and their limited geographical coverage within the plants' distributions, together with the close morphological similarities of closely-related pollinators making their identification difficult. Where two or more pollinators have been recorded as the routine pollinators of a single Ficus species they appear to be associated with same habitat or even same tree and same syconia (Kerdelhué 1997; Haine et al. 2006; Darwell et al. 2014) though usually with a prominent pollinator (Moe et al. 2011), or different habitats (Michaloud et al. 1996), or have allopatric or parapatric distributions within the ranges of their hosts (Chen et al. 2012; Bain et al. 2016; Yu et al. 2019). However, sampling intensity is again rarely sufficient to confirm this pattern of a single species of pollinator routinely servicing each Ficus species at any given location.

The assumption of extreme host specificity in fig wasps was based on a combination of the host records available and the apparent specialized co-adaptations required for a fig wasp to reproduce inside the figs of each Ficus species. Host choice by pollinators is made by the adult females and centers on long-distance plant-specific and developmental stage-specific volatile cues released by the figs when they are ready to be pollinated (van Noort et al. 1989; Grison-Pigé et al. 2002; Hossaert-Mckey et al. 2010). Pollinator females that arrive at a fig then need to be able to negotiate their way through a narrow ostiole in order to reach the flowers where they lay their eggs, and pollinator head shape is linked to the size of the ostiole (van Noort and Compton 1996). Successful oviposition once inside a fig depends on the fig wasp having an ovipositor that is longer than the styles through which its eggs are inserted (Nefdt and Compton 1996). Finally, successful development of their offspring depends on a galling response by the plant and gall forming insects are typically highly host specific (Weiblen 2004; Yu and Compton 2012; Ghana et al. 2015; Stone and Cook 1998).

Although the relationship between fig trees and their pollinators is routinely described as a mutualism, the majority of Ficus species in Asia have a dioecious breeding system, where individual trees have figs that either produce only seeds (on 'female' trees) or only pollinator offspring (on 'male' trees) (Janzen 1979; Berg 2003). This situation contrasts with fig trees with a monoecious breeding system, where all the trees have figs that can produce both seeds and support the development of pollinator offspring. Monoecious fig trees are often large free-standing trees or stranglers (hemi-epiphytes) growing at low densities in forest habitats, whereas dioecious species are typically smaller and shrubby and more likely to have aggregated distributions (Berg 1990; Yang et al. 2015). Probably reflecting these differences or different wasp ecology, some pollinators of monoecious species fly and transport pollen for long distances between trees (Nason et al. 1998; Ahmed et al. 2009) increasing the possibility of host-shift by mistakes especially in Africa and America where monoecious are figs rich and be well studied (Kerdelhué et al. 1999; Machado et al. 2001; Molbo et al. 2003; Marussich and Machado 2007; Jousselin et al. 2008; Su et al. 2008; Compton et al. 2009; McLeish and van Noort 2012; Yang et al. 2015), whereas the pollinators of dioecious Ficus species are believed to usually display more limited dispersal (Harrison and Rasplus 2006; Chen et al. 2011; Nazareno et al. 2013) which may improve the speciation by duplication across broad geographical distributions and all the co-pollinator within one host species are sisters (Yang et al. 2015; Rodriguez et al. 2017; Yu et al. 2019). Host-shift requires coexistence of fig species within the flight range of pollinators, and is affected by flowering phenology, growing density and odor similarity between the figs. When two fig species share pollinator, they usually produce the same receptive fig odor (Cornille et al. 2012; Wang et al. 2016). Even host shifts are easy to judge among unrelated fig species, but they are likely to be easier between closely related species (Rasplus 1996) and there are numerous closely-related dioecious fig trees in Asia. Fig trees planted outside their normal range may also be more likely to support multiple pollinators, if their routine pollinators are absent locally (Corner 1965; Compton 1990; Patel et al. 1993).

The extent to which fig tree species growing within a single location are supporting more than one species of pollinator can be $20 \%$ for both monoecious figs and dioecious figs in in southwest China (Yang et al. 2015), while that of the dioecious figs in New Guinea is only $1.5 \%$ (Moe et al. 2011). Most recent studies have concentrated on the pollination biology of individual species of fig trees (Chen et al. 2012; Darwell et al. 2014; Bain et al. 2016; Rodriguez et al. 2017; Yu et al. 2019), though pollinator sharing resulting in gene flow between closely-related Ficus species has nonetheless been detected (Machado et al. 2011; Wang et al. 2016). Here, we describe a Ficus 
community approach, where figs from southern China were screened for pollinator identity. The communities included mixtures of native and planted species and trees with both monoecious and dioecious breeding systems. We address the following questions (1) is there any difference on the extent of pollinator sharing between monoecious and dioecious Ficus? and (2) where two pollinators are present, does one species with predominate rate $(>85 \%)$ ? (3) is there any difference on co-pollinator across geographical distribution between monoecious and dioecious Ficus?

\section{Methods}

\section{Study site}

Fig trees were sampled mainly at two sites in Guangdong province of SE China separated by about 200 $\mathrm{km}$ : the South China Botanical Garden (N 2310'46", E113 $21^{\prime} 06^{\prime \prime}$; SCBG) with an area of 333 hectares and Dinghu Mountain (N2309'21" $1^{\prime \prime}$ E112 $30^{\prime} 39^{\prime \prime}$; DHS) with an area of 1,133 hectares. Edaphic and climatic conditions at the two sites are similar and have a subtropical monsoon climate with distinct dry and wet seasons. The dry season runs from October to March, with $80 \%$ of annual precipitation concentrated in April-September. The mean annual temperature is $21.8{ }^{\circ} \mathrm{C}$ in SCBG ( $\mathrm{Yu}$ et al. 2006) and $21.9^{\circ} \mathrm{C}$ in DHS (Han et al. 2019), and the coldest mean monthly temperatures $\left(13.1{ }^{\circ} \mathrm{C}\right.$ in SCBG and $12.6^{\circ} \mathrm{C}$ in DHS) occur in January.

More than 13,000 kinds of living tropic and subtropic plants including at least 15 fig species are preserved in SCBG. The fig trees that support pollinators at SCBG include five monoecious figs, $F$. microcarpa, $F$. benjamina, $F$. subpisocarpa, $F$. virens, $F$. altissima, and seven dioecious fig trees, F. hirta, F. triloba (one tree), F. auriculata, F. oligodon (two small trees), $F$. hispida, F. variegata var. chlorocarpa and F. pumila. In DHS, the natural vegetation comprises mainly southern subtropical monsoon evergreen broadleaved forests, reflecting moist local climatic conditions. The Ficus with pollinators present at DHS are F. microcarpa, F. benjamina, F. subpisocarpa, $F$. hirta, F. triloba, F. hispida, F. fistulosa, F. variegata var. chlorocarpa, F. oligodon, F. erecta var. beecheyana and $F$. pyriformis. The dioecious $F$. variolosa which is naturally distributed in SE China is also reported to be found in DHS, but we don't know if there are pollinators in their syconia. The $F$. auriculata in SCBG are planted though the species is naturally distributed locally. The other dioecious Ficus at the two sites had not been planted, whereas the monoecious species had been planted. In the surrounding area of SCBG and DHS, some monoecious fig species, such as $F$. microcarpa, F. benjamina, F. subpisocarpa, $F$. virens and $F$. altissima, are often planted as street trees or ornamental trees.
Three closely-related dioecious fig tree species have been recorded as sharing a single species of pollinator (Wiebes 1993) and all of them distribute in DHS. We only collected pollinators of . pyriformis in DHS and difficult to check pollinator sharing among them. So the sampling area was extended to nearby within Guangdong Province for F. erecta var. beecheyana (Conghua E 113 $57^{\prime} 9^{\prime \prime}$; N $\left.23^{\circ} 44^{\prime} 58^{\prime \prime}\right)$, F. pyriformis (DHS and Huizhou E 115 $14^{\prime} 49^{\prime \prime}$;

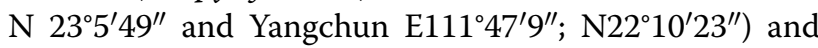
F. variolosa (DHS and Huizhou E 115 $14^{\prime} 49^{\prime \prime}$; N 23 $3^{\circ} 5^{\prime} 49^{\prime \prime}$ and Yangchun E111 $\left.47^{\prime} 9^{\prime \prime} ; \mathrm{N} 22^{\circ} 10^{\prime} 23^{\prime \prime}\right)$. Three species were naturally-established but with a little differences in habitats: F. erecta var. beecheyana usually occur in forests or along roadsides and streams; $F$. variolosa is usually in the forest and wet areas; while $F$. pyriformis is mainly found along streams (Zhou and Gilbert 2003; Tzeng et al. 2006).

\section{The study species}

In total, the study species include the pollinators of four monoecious and six dioecious fig species. The four monoecious species are big trees with crops of more than ten thousand figs. F. microcarpa and F. benjamina belong to subgenus Urostigma section Urostigma subsection Conosycea, while $F$. subpisocarpa and $F$. virens belong to the subsection Urostigma. Among the dioecious species, F. hispida and F. fistulosa are small trees belonging to subgenus Sycomorus section Sycocarpus subsection Sycocarpus (Cruaud et al. 2012), while F. oligodon and F. auriculata are two closely related small trees belonging to section Sycomorus subsection Neomorphe (Berg 2004). F. hirta and F. triloba belong subgenus Ficus subsection Eriosycea. F. hirta is a shrub whereas F. triloba is a small tree with larger crops. F. erecta var. beecheyana, F. pyriformi and $F$. variolosa belong subsection Frutescentiae are small shrubs. The monoecious species produce largely synchronous crops, and most of dioecious fig species present well defined crops even though there may be somewhat less synchronization (Yang et al. 2002; Tzeng et al. 2006). The exception is $F$. hirta which usually exhibit asynchronous within-tree fruiting with figs of different developmental stages present for longer periods on the plants (Yu et al. 2006).

\section{Fig wasp DNA extraction, amplification and analysis}

The pollinators were identified using DNA sequencing (Table 1). The mitochondrial genetic marker mtCOI was sequenced from an average of 23.2 fig wasp individuals reared from male figs of each Ficus species (range $8-35$, total 301). Five fig wasp genera were represented (Tables 1,2). All the sequenced fig wasps were adult offspring and therefore had developed successfully in the fig tree species from which they were reared. 
Table 1 The identities and haplotypes of pollinators reared from figs in Southern China

\begin{tabular}{|c|c|c|c|c|c|c|}
\hline Ficus species & Location & $\begin{array}{l}\text { Insects } \\
\text { genotyped }\end{array}$ & $\mathrm{N}$ trees & N figs & Pollinators & Haplotypes (frequency when $>1$ ) \\
\hline F. microcarpa & SCBG & 19 & 4 & 18 & Poll. 1. Eupristina verticillata agg. & $\mathrm{H} 1(18) ; \mathrm{H} 2$ \\
\hline F. benjamina & SCBG & 30 & 5 & 13 & Poll. 1. Eupristina sp. 1 & $\mathrm{H} 1 ; \mathrm{H} 2(2) ; \mathrm{H} 3(13) ; \mathrm{H} 4(11) ; \mathrm{H} 5 ; \mathrm{H} 6 ; \mathrm{H} 7$ \\
\hline F. subpisocarpa & SCBG & 35 & 2 & 30 & $\begin{array}{l}\text { Poll. 1. Platyscapa cf. hsui sp. } 1 \\
\text { Poll. 2. Platyscapa cf. hsui sp. } 2\end{array}$ & $\begin{array}{l}\mathrm{H} 1(2) ; \mathrm{H} 2(2) ; H 3 ; H 4(2) ; H 5 ; H 6(2) ; \\
\mathrm{H} 7(8) ; H 8 ; H 9 ; H 10 ; H 11 ; H 12 ; H 13 ; H 14 ; \\
\mathrm{H} 15(2) ; H 16(2) ; H 17(2) ; H 18(2) \\
H 1(2)\end{array}$ \\
\hline F. virens & SCBG & 8 & 1 & 7 & Poll. 1. Platyscapa coronata & $\mathrm{H} 1(3) ; \mathrm{H} 2 ; \mathrm{H} 3(4)$ \\
\hline F. auriculata & SCBG & 31 & 1 & 13 & $\begin{array}{l}\text { Poll. } 1 \text { Ceratosolen cf. emarginatus } \\
\text { sp. } 1 \\
\text { Poll. } 2 \text { Ceratosolen cf. emarginatus } \\
\text { sp. } 2\end{array}$ & $\begin{array}{l}\mathrm{H} 1 ; \mathrm{H} 2(29) \\
\mathrm{H} 1\end{array}$ \\
\hline F. oligodon & DHS & 29 & 1 & 8 & $\begin{array}{l}\text { Poll. } 1 \text { Ceratosolen cf. emarginatus } \\
\text { sp. } 2 \\
\text { Poll. } 2 \text { Ceratosolen } \\
\text { cf. emarginatus sp. } 1 \\
\text { Poll. } 3 \text { Blastophaga sp. } 1\end{array}$ & $\begin{array}{l}\mathrm{H} 1(23) ; \mathrm{H} 2(2) ; \mathrm{H} 3 \\
\mathrm{H} 1 \\
\mathrm{H} 1(2)\end{array}$ \\
\hline F. hispida & SCBG & 22 & 9 & 22 & Poll. 1. Ceratosolen solmsi marchali & $\mathrm{H} 1 ; \mathrm{H} 2(20) ; \mathrm{H} 3$ \\
\hline F. hispida & DHS & 6 & 2 & 6 & Poll. 1. Ceratosolen solmsi marchali & $\mathrm{H} 2(5) ; \mathrm{H} 4$ \\
\hline F. fistulosa & DHS & 18 & 4 & 14 & Poll. 1. Ceratosolen hewitti & $\mathrm{H} 1(17) ; \mathrm{H} 2$ \\
\hline F. hirta & SCBG & 8 & 8 & 8 & Poll. 1. Valisia javana hilli & $\mathrm{H} 4(4) ; \mathrm{H} 6 ; \mathrm{H} 7 ; \mathrm{H} 8 ; \mathrm{H} 9$ \\
\hline F. hirta & DHS & 10 & 7 & 7 & Poll. 1. Valisia javana hilli & $\mathrm{H} 1(2) ; \mathrm{H} 2 ; \mathrm{H} 3(2) ; \mathrm{H} 4(4) ; \mathrm{H} 5$ \\
\hline F.triloba & SCBG & 1 & 1 & 1 & Poll. 2. Valisia javana hilli & $\mathrm{H} 1$ \\
\hline F. triloba & DHS & 21 & 9 & 17 & $\begin{array}{l}\text { Poll. 1. Valisia esquirolianae } \\
\text { Poll. 2. Valisia javana hilli }\end{array}$ & $\begin{array}{l}\mathrm{H} 1(5) ; \mathrm{H} 2 ; \mathrm{H} 3(2) ; \mathrm{H} 4 ; \mathrm{H} 5 \\
\mathrm{H} 1(8) ; \mathrm{H} 2(3)\end{array}$ \\
\hline F. erecta var. beecheyana & Conghua & 29 & 6 & 25 & Poll. 1. Blastophaga sp. 1 & $\mathrm{H} 1(8) ; \mathrm{H} 2(14) ; \mathrm{H} 3 ; \mathrm{H} 4 ; \mathrm{H} 5 ; \mathrm{H} 6(3) ; \mathrm{H} 7$ \\
\hline F.pyriformis & DHS & 3 & 1 & 3 & Poll. 1. Blastophaga sp. 1 & $\mathrm{H} 4, \mathrm{H} 9(2)$ \\
\hline F.pyriformis & Huizhou & 6 & 1 & 3 & Poll. 1. Blastophaga sp. 1 & $\mathrm{H} 1(2), \mathrm{H} 2, \mathrm{H} 4, \mathrm{H} 6(2)$ \\
\hline F.pyriformis & Yangchun & 16 & 1 & 6 & $\begin{array}{l}\text { Poll. 1. Blastophaga sp. } 1 \\
\text { Poll. 2. Ceratosolen sp. } 1\end{array}$ & $\begin{array}{l}\mathrm{H} 2(4), \mathrm{H} 8(2), \mathrm{H} 9(9) \\
\mathrm{H} 1\end{array}$ \\
\hline F. variolosa & Dangan Island & 9 & 1 & 3 & Poll. 1. Blastophaga sp. 1 & $\mathrm{H} 1(9)$ \\
\hline
\end{tabular}

Genomic DNA was extracted from the whole body of each fig wasp using the EasyPure Genomic DNA Extraction Kit (TransGen, Beijing, China). A 435-710 bp fragment of the mtCOI gene for each pollinating species was then sequenced following the protocol used in previous studies (Tian et al. 2015). The reaction was optimized and programmed on a MJ Thermal Cycler (PTC 200) as one cycle of denaturation at $94{ }^{\circ} \mathrm{C}$ for $5 \mathrm{~min}, 35$ cycles of $30 \mathrm{~s}$ denaturation at $94{ }^{\circ} \mathrm{C}, 30 \mathrm{~s}$ at a $55^{\circ} \mathrm{C}$ annealing temperature, and $30 \mathrm{~s}$ extension at $72{ }^{\circ} \mathrm{C}$, followed by $8 \mathrm{~min}$ extension at $72{ }^{\circ} \mathrm{C}$. All amplified PCR products were purified using QIAquick spin columns (Qiagen) and were sequenced in an ABI 3730xl capillary sequencer using BigDye Terminator V 3.1 chemistry (Applied Biosystems). All unique haplotype sequences were deposited in GenBank (accession numbers: MW851213-MW851283).

We did not detect any indications of pseudo-genes, such as multiple peaks in chromatograms, stop codons or frame shift mutations (Song et al. 2008). Sequences were aligned using MUSCLE (Edgar 2004) implemented in MEGA 6.0 (Tamura et al. 2013) with manual corrections. DnaSP 5.0 was used to count the number of haplotypes (Librado and Rozas 2009). Maximum likelihood trees were constructed using Kimura-2-parameter (K2P) model by MEGA 6.0 (Tamura et al. 2013) with uniform rates for COI, and node supports were assessed based on 2000 bootstrap replicates. K2P distances within and between clades for COI haplotypes were then summarized. The clades with high gene sequence differences (larger than 0.02), were blasted to Genbank with the first 1-3 sequences sorted by percent identity. In order to determine whether pollinators collected from the same fig tree but with different geographical distribution are the same species, we further added pollinator sequences of $F$. benjamina and $F$. virens in Xishuangbanna and $F$. erecta var. beecheyana in Taiwan (Additional file 2: Appendix excel 1). Two species of non-pollinating fig wasps 


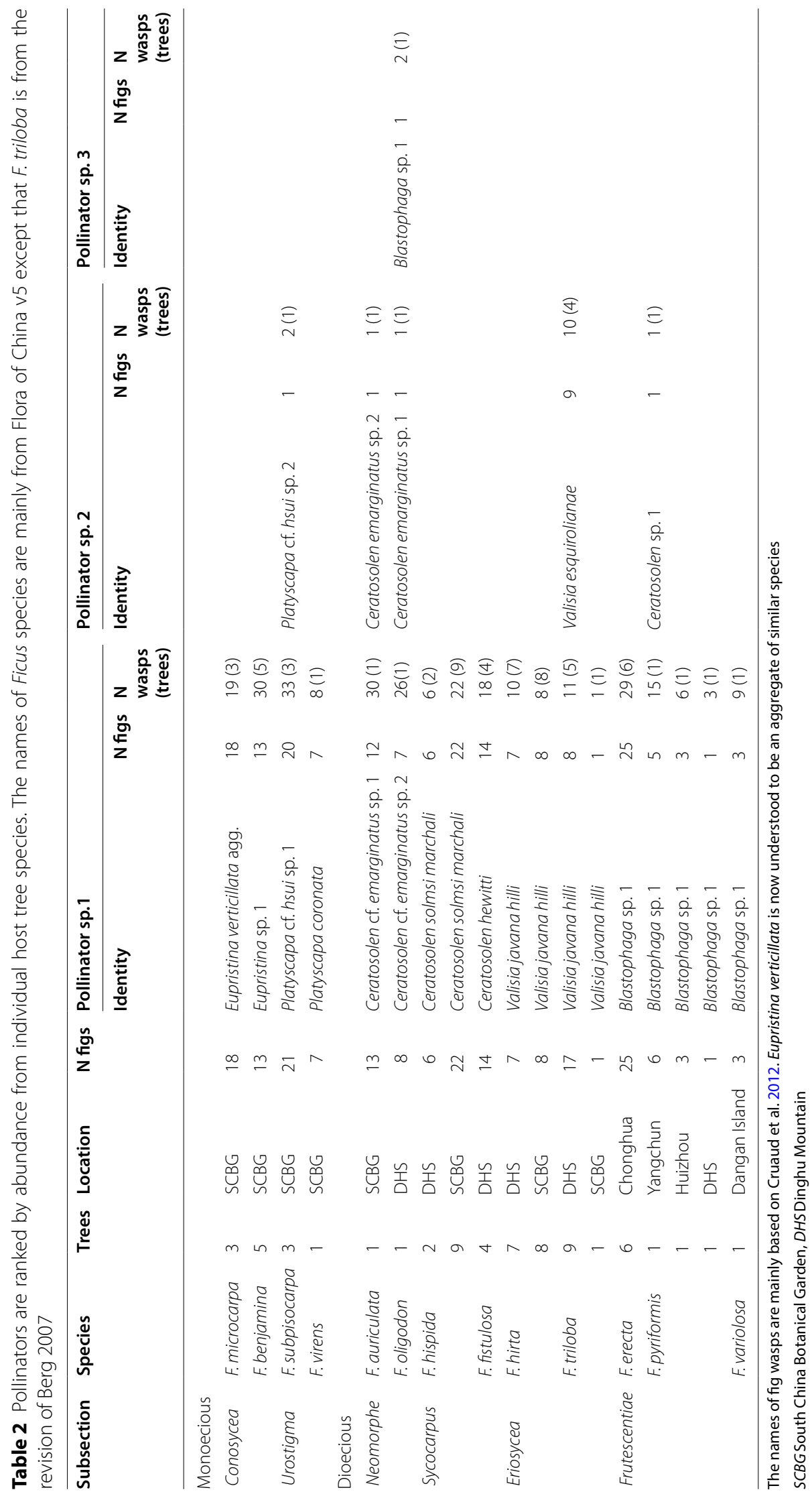


reared from F. hirta, Sycoscapter hirticola (MG548706) and Philotrypesis josephi (MG548673 and MG548674, both Pteromalidae) were included as outgroups ( $\mathrm{Yu}$ et al. 2018).

\section{Results}

The breakdown of 1:1 specificity among sympatric monoecious and dioecious fig species

Phylogenetic analyses of the COI sequences detected 13 pollinator species that had reproduced within the figs of the 13 Ficus species, but there was not a 1:1 concordance between them. All the pollinator clades were strongly supported (Fig. 1; Table 1), with low within-clade and large between-clade K2P distances (Additional file 1: Table S1) and the cumulative distribution of K2P distances indicating a marked barcoding gap between clades (Fig. 2). We therefore treat each clade as a distinct species. Based on the sequences downloaded from GenBank and our de novo sequencing we detected numerous examples of pollinators associated with more than one Ficus species and of Ficus species supporting the development of more than one species of pollinator. Up to three different species of pollinators were reared from the figs of a single host species and up to four host taxa were recorded for a single species of pollinator (Table 2).

The classical 1:1 pollinator and host Ficus relationship was only detected among two dioecious Ficus species $(F$. hispida and F. fistulosa), but it was the norm among the monoecious fig trees, where no pollinator-sharing was detected. Ficus subpisocarpa nonetheless supported the development of two closely-related fig wasps with 0.051 K2P distance between them, rather than one (Table 2; Fig. 1). As reported previously based on morphological identifications, the same pollinator species (Blastophaga sp. 1) was reared from F. erecta var. beecheyana, F. pyriformis and $F$. variolosa, but in addition the same species

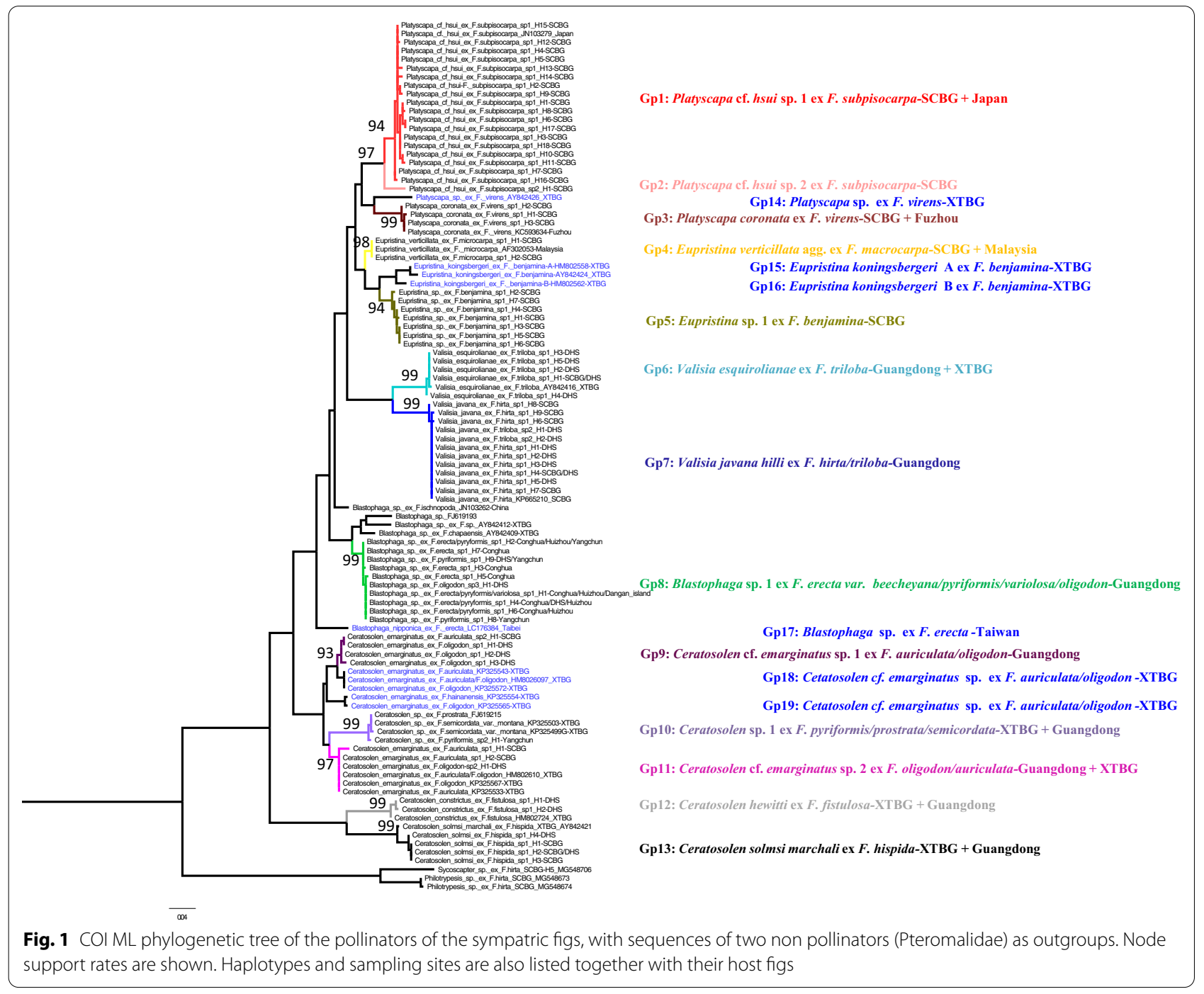




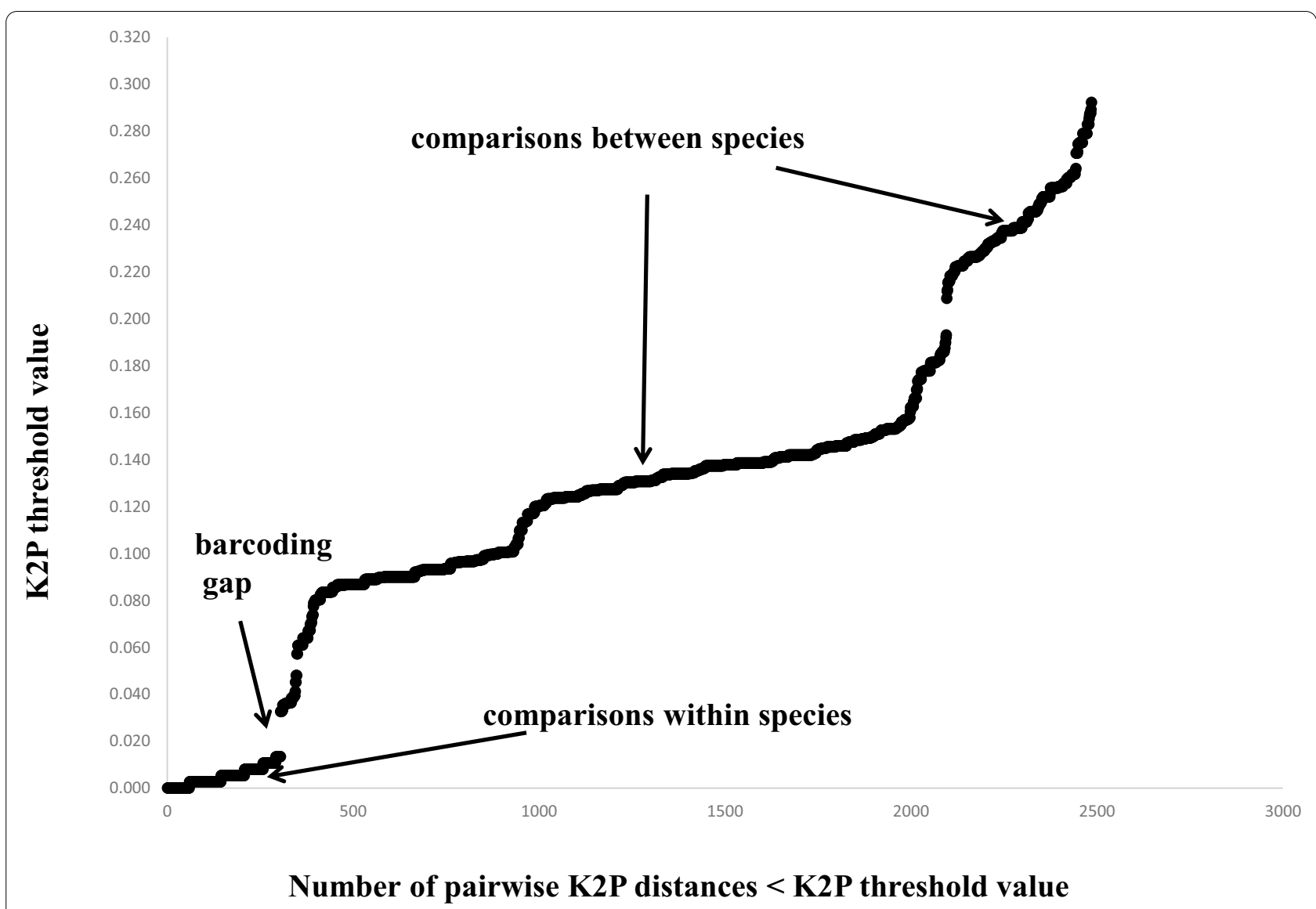

Fig. 2 Cumulative distribution of Kimura pairwise genetic distances (K2P) for COI of pollinators associated with Ficus species. Intraspecific distance ranged between 0-1.3\% and interspecific distances ranged from 3.3-29.2\%. A marked barcoding gap separated the within- and between-putative species pairwise distances

of fig wasp was also reared from figs of F. oligodon, an unrelated fig tree. F. oligodon was routinely supporting two species of Ceratosolen, both of which were shared with $F$. auriculata but no other species. The closely related taxa F. hirta and F. triloba also shared a pollinator (Valisia javana hilli) which was not reared from any other hosts.

Each fig wasps were generally reared from one or two host species (Table 2; Fig. 1). Ficus species supporting more than one species of fig wasp generally had one predominant pollinator that provided between 88 and $97 \%$ of the total reared individuals. The exception was $F$. triloba where its two pollinators were present in roughly equal proportions (Fig. 3; Table 1). Around half of the pollinators reared from $F$. triloba were $V$. javana hilli, a species routinely associated with $F$. hirta ( $V$. javana complex sp. 1 in Yu et al. 2019).

\section{Pollinator diversity in monoecious and dioecious figs with allopatric distribution}

Five cases of allopatric co-pollinator were observed, two in monoecious figs and three in dioecious figs (Fig. 1). Deep COI gene sequence divergence between subclades can be larger than $10.0 \%$ in the pollinator of $F$. virens (Grp3 and Grp14) and F. erecta var. beecheyana (Grp8 and Grp17), or about $6 \%$ in the pollinator of $F$. benjamina (Grp5 and Grp15 or Grp5 and Grp16) and F. oligodon (Grp9 and Grp19), or $1.9 \%$ in the pollinator of both $F$. auriculata and F. oligodon (Grp9 and Grp18) (Additional file 1: Table S1).

At the same time, eight cases of same pollinator with broad geographical distribution were observed, three in monoecious figs and five in dioecious figs (Fig. 1). The geographical distribution of three monoecious figs with same pollinator species are different with the longest distance between SCBG and Malaysia for F. microcarpa (Grp4), the middle one between SCBG and Japan for F. subpisocarpa (Grp1), and the shortest one between SCBG and Fuzhou for F. virens (Grp3). While those of 


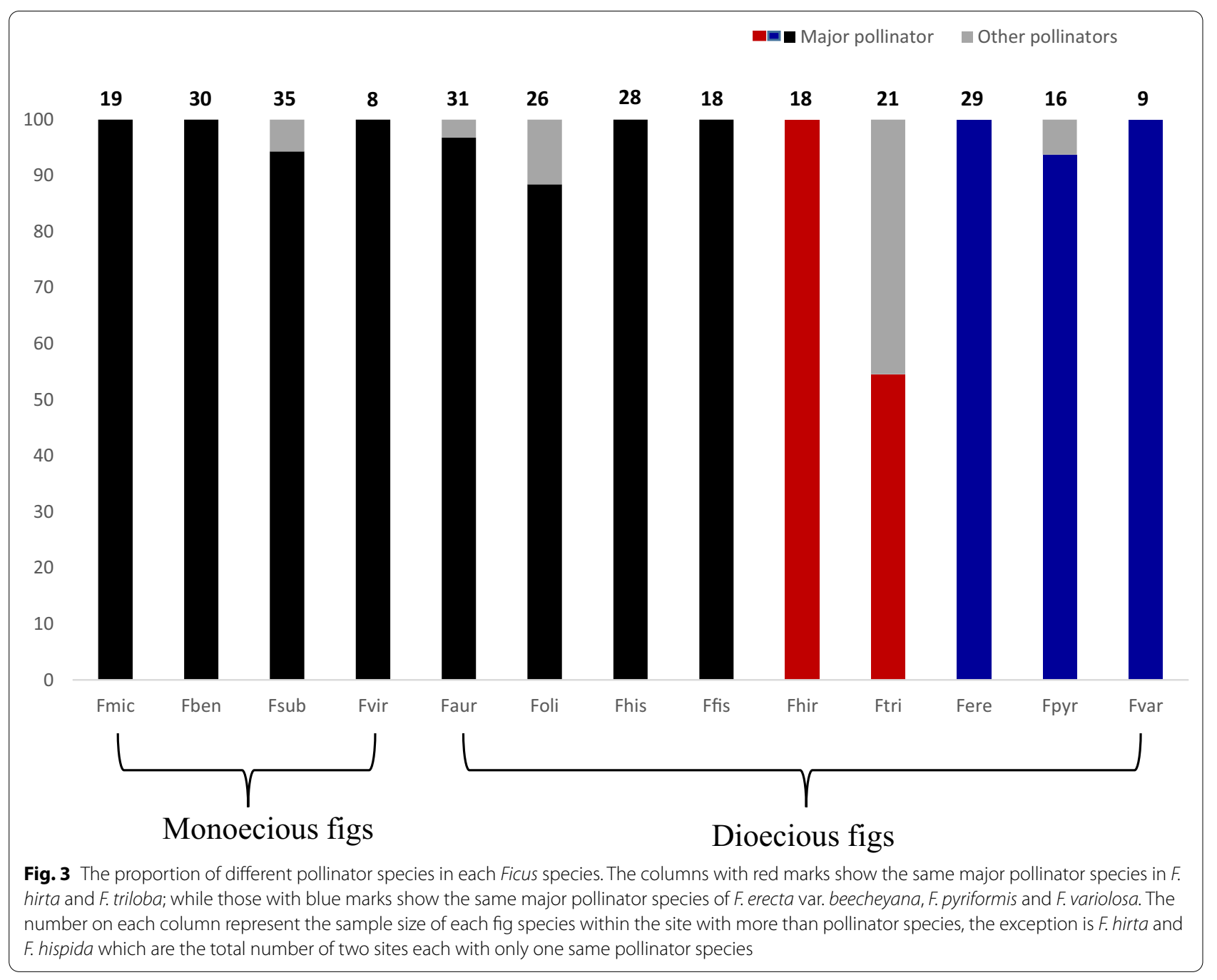

five dioecious figs, F. hispida (Grp13), F.fistulosa (Grp12), F. triloba (Grp6), F. auriculata and F. oligodon (Grp11) are all between SCBG and XTBG.

\section{Discussion}

Our COI screening detected numerous examples of pollinator fig wasp species entering and successfully reproducing in more than a single host Ficus in southern China. Host overlap was frequent among pollinators of dioecious species and in most cases involved pairs of fig wasp species where one pollinator predominated and a second was reared only rarely. One interpretation of this is that the more rarely encountered pollinator species had other hosts where they were more abundant, but our screening across different Ficus species was not sufficiently extensive to confirm this and in some cases the pollinator species may simply be rare within our sampling area. Most examples of fig wasps developing in figs of more than one host involved fig trees that were closely related, but there were exceptions involving species of Blastophaga and Ceratosolen that were reared from figs normally associated with the other genus of pollinators though more samples need to be checked to confirm. Fig wasp offspring developing successfully in unrelated host Ficus has been recorded previously from Africa (van Noort et al. 2013). This ability to develop inside hosts that are phylogenetically distant shows that the host specificity of fig wasps may be determined more by the choices made by searching adult females than by any physiological limitations, and sometimes competition among fig wasps may also be involved.

Even within the Ficus species we sampled the size of the samples was not extensive and we are unlikely to have detected the full range of Ficus hosts being utilized locally by the fig wasps. There was generally one routine pollinator species combined with rarer entries by two or more additional pollinators (Moe et al. 2011; Darwell et al. 2014; Yang et al. 2015). An exception to the general pattern of pollinator sharing where one pollinator species 
predominant was provided by F. triloba, where two pollinator species were present in roughly equal numbers of its figs, but more samples, taken throughout the year, will be needed to confirm this pattern. While for its related fig, F. hirta, with a sampling throughout the range of the species from south China, Thailand to Indonesia, generally a single species was found, suggesting that mainly specialist pollinators in this species (Yu et al. 2019). Some of the trees we sampled were planted individuals (e.g. $F$. auriculata in SCBG) and this may have increased the extent of pollinator sharing that we detected. Our results nonetheless suggest that exceptions to the 'classical' one pollinator to one tree relationship are routine among sympatric dioecious fig tree species in southern China, to the extent that among trees with this breeding system strict specificity is the exception, not the norm.

Fig wasps develop inside figs on male trees of dioecious fig trees, but it is likely that similar entry by two or more pollinator species is taking place in both male and female figs. Pollinator host choice, based mainly around species-specific volatile attractants released by receptive figs, is the major isolating mechanism that helps prevent heterospecific pollen being deposited on the flowers inside female figs, but is not always effective (Souto-Vilarós et al. 2018). Other isolating mechanisms such as pollen incompatibility appear to be poorly developed in Ficus (Huang et al. 2019), so whenever fig wasp species are entering female figs of two more host trees in an area there is the possibility of viable hybrid seed being developed. Hybrids can mature successfully and can lead to backcrossing and introgression between species though hybrids are not common in nature (Parrish et al. 2003; Wilde et al. 2020). Some artificially generated hybrids appear to be at no reproductive disadvantage in terms of seed production, but male hybrid offspring can be sterile because pollinators cannot develop inside their figs (Ghana et al. 2015, but see also Yakushiji et al. 2012), so patterns of introgression may be complex. Meanwhile, fig species are classical plants too and the factors limiting interspecific introgression has more to do with counterselection of hybrids than to strict pollination specificity.

Sharing of pollinators was not a feature of the monoecious fig tree species we sampled, though we still need a long-term survey of more samples. In addition, the monoecious figs in our study are mainly planted, and hence their fauna may be depauperated, which may explain fewer pollinator species in monoecious figs at some certain. Indeed, at XTBG, both $F$. microcarpa and $F$. altissima are visited by two Agaonid species, one pollinator and one cheater become from pollinator (Peng et al. 2008; Chen et al. 2013; Zhang et al. 2019, 2021). F. benjamina in XTBG also have two related species of pollinator (Yang et al. 2015).
Monoecious and dioecious fig trees differ in numerous ways that may influence pollinator behavior including growth form (trees versus shrubs), flowering phenology (large synchronous crops versus smaller asynchronous crops) and the generally more clumped distribution of dioecious species (monoecious species are often more dispersed). Perhaps more significantly in our study area and across SE Asia, there an exceptionally high diversity of dioecious species, most of which are pollinated by fig wasps that belong to a small number of genera. Opportunities for chance landing on figs of atypical hosts are therefore greater for those insects associated with dioecious hosts, but in addition most of the sharing of pollinators was between closely related dioecious species, which are likely to be generating relatively similar attractant cues by selection (Wei et al. 2014; Wang et al. 2016). The morphology of closely-related pollinator fig wasps is often very similar, and our results emphasize that pollinator-sharing is likely to have been under-estimated because of this. Barcoding and other molecular identification techniques are used increasingly to distinguish between fig wasp species, but our results also highlight the need to sequence fig wasps from several figs, even if they look alike, in order to detect pollinator species that may be present at low frequencies. More than one morphologically similar species can even be reproducing within the same individual figs (Sutton et al. 2017).

On the other hand, our results checked co-pollinator within one fig species across broad geographic distribution. For the monoecious figs with long dispersed pollinators, the same fig species can be pollinated by the same species of pollinator in a wide geographical range, such as F. microcarpa from SCBG to Malaysia, and F. subpisocarpa from SCBG to Japan which across a strait. The same case is in monoecious $F$. racemosa which can have same pollinator species across China-Thailand (Kobmoo et al. 2010; Bain et al. 2016). However, it is also possible for them having different pollinator species within short distance even in the same site. For example, F. benjamina in XTBG has two different related species (Yang et al. 2015), which may be due to niche differentiation or transferred from other related species. While for the dioecious figs, dispersing ability of the pollinators according to their ecotypes, plant size and canopy height (Yang et al. 2015) also play a certain decisive role in number of co-pollinators. As a small tree, five dioecious figs in our study can have the same pollinator species between SCBG and XTBG, although there is genetic differentiation in some of them. While for shrub species, such as $F$. hirta and $F$. erecta var beecheyana, they can differentiate into different species at a shorter geographical distance (Yu et al. 2019; Wachi et al. 2016). 


\section{Conclusions}

Our survey of the fig wasp pollinators associated with local assemblages of Ficus species in Southern China revealed contrasting pollinator relationships between monoecious and dioecious trees. Monoecious trees and their pollinators largely displayed a highly specific one pollinator for one tree association though more monoecious figs here are cultivated, and still need extensive sampling. Among dioecious species there was no such specificity, with frequent sharing of pollinators across trees and two or more species of pollinators associated with each tree species. Possible biological traits favoring this breakdown in pollinator specificity among dioecious Ficus include their extended asynchronous flowering phenologies and the mixtures of closely-related species that can grow in close proximity. This lack of specificity suggests that the extent of pollen flow between dioecious fig tree species is likely to have been underestimated, with unknown consequences. In addition, our results combined with other published sequences show that the dispersing distance of pollinators can determine the number of co-pollinators across a broad geographical distribution to a certain extent.

\section{Abbreviations}

SCBG: South China Botanical Garden; DHS: Dinghu Mountain; XTBG: Xishuangbanna Tropical Botanical Garden; DNA: Deoxyribonucleic acid; mtCOI: Mitochondrial cytochrome oxidase I; COI: Cytochrome oxidase I; K2P: Kimura-2-parameter.

\section{Supplementary Information}

The online version contains supplementary material available at https://doi. org/10.1186/s40529-021-00323-8.

Additional file 1: Table S1. COI gene sequence differences (Kimura2-parameter) within (diagonal) and between groups (below diagonal). Within groups differences are low (highlighted in green) and are assumed to belong to the same species. Grp 1: Platyscapa cf. hsui sp. 1 ex F. subpisocarpa; Grp 2: Platyscapa cf. hsui sp. 2 ex F. subpisocarpa; Grp 3: Platyscapa coronata ex F. virens; Grp 4: Eupristina verticillata agg. ex F. microcarpa; Grp5: Eupristina sp. 1 ex F. benjamina; Grp 6: Blastophaga sp. 1 ex F. erecta var. beecheyana/pyriformis/variolosa/oligodon; Grp 7: Valisia esquirolianae ex F. triloba; Grp 8: Valisia javana hilli ex F. hirta/triloba; Grp 9: Ceratosolen sp. 1 ex F. pyriformis/prostrata/semicordata montana; Grp10: Ceratosolen cf. emarginatus sp.1 ex F. auriculata/oligodon; Grp 11: Ceratosolen cf. emarginatus sp. 2 ex F. oligodon/auriculata; Grp 12: Ceratosolen hewitti ex F. fistulosa; Grp13: Ceratosolen solmsi marchali ex F. hispida. Grp14-19 contain the COI sequences of pollinator from some published papers. Grp 14: Platyscapa sp. ex F. virens from XTBG (Jiang et al. 2006); Grp 15-16: Eupristina koningsbergeri $A$ and B ex F. benjamina from XTBG (Jiang et al. 2006; Yang et al. 2015); Grp 17: Blastophaga sp. ex F. erecta from Taiwan (Wachi et al. 2016); Grp 18-19: Cetatosolen cf. emarginatus sp. ex F. auriculata/oligodon from XTBG (Wang et al. 2016).

Additional file 2: Appendix. Information of $\mathrm{COI}$ sequences used in this study. S1.1 List of pollinator sequences amplified by this study. S1.2 List of pollinator sequences downloaded from GenBank used in Fig. 1.
Author's contributions

YH designed the research and analyzed data. LYL, CYF and JYX performed laboratory work. CYF also collected samples. YH, CS and SGC co-wrote the manuscript. All authors read and approved the final manuscript.

\section{Funding}

This work was supported by the National Natural Science Foundation of China (31630008; 31971568), Key Special Project for Introduced Talents Team of Southern Marine Science and Engineering Guangdong Laboratory (Guangzhou) (GML2019ZD0408), and Province Natural Science Foundation of Guangdong (c20140500001306). Jia Yongxia is grateful for support from Technical Innovation Project of Instrument and Equipment function of CAS.

\section{Availability of data and materials}

All unique haplotype sequences of $\mathrm{COI}$ sequence for all the sampled pollinators were deposited in GenBank (accession numbers: MW851213-MW851283).

\section{Declarations}

Ethics approval and consent to participate

Not applicable.

\section{Consent for publication}

Not applicable.

\section{Competing interests}

The authors declare that they have no conflict interests.

\section{Author details}

${ }^{1}$ Plant Resources Conservation and Sustainable Utilization, South China Botanical Garden, The Chinese Academy of Sciences, Guangzhou 510650, China. ${ }^{2}$ Southern Marine Science and Engineering Guangdong Laboratory (Guangzhou), Guangzhou 511458, China. ${ }^{3}$ Centre for Plant Ecology, CAS Core Botanical Gardens, Guangzhou, China. ${ }^{4}$ School of Biology, University of Leeds, Leeds LS2 9JT, UK.

Received: 16 April 2021 Accepted: 21 September 2021

Published online: 09 October 2021

\section{References}

Ahmed S, Compton SG, Butlin RK, Gilmartin PM (2009) Wind-borne insects mediate directional pollen transfer between desert fig trees 160 kilometers apart. PNAS 106:20342-20347

Bain A, Borges RM, Chevallier MH, Vignes H, Kobmoo N, Peng YQ (2016) Geographic structuring into vicariant species-pairs in a wide-ranging, high dispersal plant-insect mutualism: the case of Ficus racemosa and its pollinating wasps. Evol Ecol 30:663-684

Berg CC (1989) Classification and distribution of Ficus. Experientia 45:605-611

Berg CC (1990) Reproduction and evolution of Ficus (Moraceae): traits connected with the adequate rearing of pollinators. Mem New York Bot Gard 55:169-185

Berg CC (2003) Flora Malesiana precursor for the treatment of Moraceae 1: the main subdivision of Ficus: the subgenera. Blumea 48:167-178

Berg CC (2004) Flora Malesiana precursor for the treatment of Moraceaea 6: Ficus subgenus Sycomorus. Blumea 49:155-200

Chen Y, Jiang ZX, Compton SG, Liu M, Chen XY (2011) Genetic diversity and differentiation of the extremely dwarf Ficus tikoua in South-western China. Biochem Sys Ecol 39:441-448

Chen Y, Compton SG, Liu M, Chen XY (2012) Fig trees at the northern limit of their range: the distributions of cryptic pollinators indicate multiple glacial refugia. Mol Ecol 21:1687-1701

Chen YL, Sun LL, Wu LL, Wu WS, Yan JY, Liu Y (2013) The genetic evolutionary relationships of two Eupristina species on Ficus altissima. Acta Ecol Sin 33:6058-6064 
Compton SG (1990) A collapse of host specificity in some African fig wasps. S Afr J Sci 86:39-40

Compton SG, Grehan K, van Noort S (2009) A fig crop pollinated by three or more species of agaonid fig wasps. Afr Entomol 17:215-222

Condit IJ (1950) An interspecific hybrid in Ficus. J Hered 41:165-168

Corner EJH (1965) Check List of Ficus in Asia and Australasia, with keys to identification. Gard Bull Singapore 21:1-186

Cornille A, Underhill JG, Cruaud A, Hossaert-McKey M, Johnson SD, Tolley KA et al (2012) Floral volatiles, pollinator sharing and diversification in the fig-wasp mutualism: insights from Ficus natalensis, and its two wasp pollinators (South Africa). Proc R Soc B 279:1731-1739

Cruaud A, Rønsted N, Chantarasuwan B, Chou L, Clement WL, Couloux A et al (2012) An extreme case of plant-insect codiversification: figs and figpollinating wasps. Sys Biol 61:1029-1047

Darwell CT, Al-Beidh S, Cook JM (2014) Molecular species delimitation of a symbiotic fig-pollinating wasp species complex reveals extreme deviation from reciprocal partner specificity. BMC Evol Biol 14:189

Edgar RC (2004) MUSCLE: a multiple sequence alignment method with reduced time and space complexity. BMC Bioinformatics 5:113

Ghana S, Suleman N, Compton SG (2015) Ability to gall: the ultimate basis of host specificity in fig wasps? Ecol Entomol 40:280-291

Grison-Pigé L, Bessière JM, Hossaert-McKey M (2002) Specific attraction of fig-pollinating wasps: role of volatile compounds released by tropical figs. J Chem Ecol 28:283-295

Haine ER, Martin J, Cook JM (2006) Deep mtDNA divergences indicate cryptic species in a fig-pollinating wasp. BMC Evol Biol 6:83

Han TT, Lu HF, Ren H, Wang J, Song GM, Hui DF et al (2019) Are reproductive traits of dominant species associated with specific resource allocation strategies during forest succession in southern China? Ecol Indic 102:538-546

Harrison RD (2005) Figs and the diversity of tropical rainforests. Bioscience 55:1053-1064

Harrison RD, Rasplus JY (2006) Dispersal of fig pollinators in Asian tropical rain forests. J Trop Ecol 22:631-639

Hossaert-Mckey M, Soler C, Schatz B, Proffit M (2010) Floral scents: their roles in nursery pollination mutualisms. Chemoecology 20:75-88

Huang JF, Xu R, Peng YQ (2019) Research progress of interspecific hybridization in genus Ficus. Biodivers Sci 27:457-467

Janzen DH (1979) How to be a fig. Ann Rev Ecol Syst 10:13-51

Jousselin E, van Noort S, Berry V, Rasplus RY, Rønsted N, Erasmus JC et al (2008) One fig to bind them all: host conservatism in a fig wasp community unraveled by conspeciation analyses among pollinating and nonpollinating fig wasps. Evolution 62:1777-1797

Kerdelhue' C, Hochberg ME, Rasplus JY (1997) Active pollination of Ficus sur by two sympatric fig wasp species in West Africa. Biotropica 29:69-75

Kerdelhue' C, Clainche IL, Rasplus JY (1999) Molecular phylogeny of the Ceratosolen species pollinating Ficus of subgenus Sycomorus sensu stricto: biogeographical history and origins of the species-specificity breakdown cases. Mol Phylogenet Evol 11:401-414

Kobmoo N, Hossaert-McKey M, Rasplus JY, Kjellberg F (2010) Ficus racemosa is pollinated by a single population of a single agaonid wasp species in continental South-East Asia. Mol Ecol 19:2700-2712

Librado P, Rozas J (2009) DnaSP v5: a software for comprehensive analysis of DNA polymorphism data. Bioinformatics 25:1451-1452

Lopez-Vaamonde C, Rasplus JY, Weiblen G, Cook JM (2001) DNA-based phylogenies of fig wasps: partial cocladogenesis between pollinators and parasites. Mol Phylogenet Evol 21:55-71

Machado CA, Jousselin E, Kjellberg F, Compton SG, Herre EA (2001) Phylogenetic relationships, historical biogeography and character evolution of fig-pollinating wasps. Proc R Soc Lond B 268:685-694

Marussich WA, Machado CA (2007) Host-specificity and coevolution among pollinating and nonpollinating New World fig wasps. Mol Ecol 16:1925-1946

McLeish M, van Noort S (2012) Codivergence and multiple host species use by fig wasp populations of the Ficus pollination mutualism. BMC Ecol Evol 12:1

Michaloud G, Carrière S, Kobbi M (1996) Exceptions to the one: one relationship between African fig trees and their fig wasp pollinators: possible evolutionary scenarios. J Biogeogr 23:513-520
Moe AM, Rossi DR, Weiblen GD (2011) Pollinator sharing in dioecious figs (Ficus: Moraceae). Biol J Linn Soc 103:546-558

Molbo D, Machado CA, Sevenster JG, Laurent Keller L, Herre EA (2003) Cryptic species of fig-pollinating wasps: implications for the evolution of the fig-wasp mutualism, sex allocation, and precision of adaptation. PNAS 100:5867-5872

Nason JD, Herre EA, Hamrick J (1998) The breeding structure of a tropical keystone plant resource. Nature 391:685-687

Nazareno AG, Alzate-Marin AL, Pereira RA (2013) Dioecy, more than monoecy, affects plant spatial genetic structure: the case study of Ficus. Ecol Evol 3:3495-3508

Nefdt RJC, Compton SG (1996) Regulation of seed and pollinator production in the fig-fig wasp mutualism. J Anim Ecol 65:170-182

Parrish TL, Koelewijn HP, van Dijk PJ (2003) Genetic evidence for natural hybridization between species of dioecious Ficus on island populations. Biotropica 35:333-343

Patel A, Hossaert-McKey M, McKey D (1993) Ficus-pollinator reserch in India: past, present and future. Curr Sci 65:243-253

Peng YQ, Duan ZB, Yang DR, Rasplus JY (2008) Co-occurrence of two Eupristina species on Ficus altissima in Xishuangbanna, SW China. Symbiosis 45:9-14

Ramírez BW (1970) Host specificity of fig wasps (Agaonidae). Evolution 24:681-691

Rasplus JY (1996) The one-to-one species specificity of the Ficus-Agaoninae mutualism: how casual? In: van der Maesen LJG (ed) The biodiversity of African plants. Kluwer Academic Publishers, The Netherlands, pp 639-649

Rodriguez L, Bain A, Chou LS, Conchou L, Cruaud A, Gonzales R et al (2017) Diversification and spatial structuring in the mutualism between Ficus septica and its pollinating wasps in insular South East Asia. BMC Evol Biol 17:207

Song H, Buhay JE, Whiting MF, Crandall KA (2008) Many species in one: DNA barcoding overestimates the number of species when nuclear mitochondrial pseudogenes are coamplified. PNAS 105:13486-13491

Souto-Vilarós D, Proffit M, Buatois B, Rindos M, Sisol M, Kuyaiva T et al (2018) Pollination along an elevational gradient mediated both by floral scent and pollinator compatibility in the fig and fig-wasp mutualism. J Ecol 106:2256-2273

Stone GN, Cook JM (1998) The structure of cynipid oak galls: patterns in the evolution of an extended phenotype. Proc R Soc B 265:979-988

Su ZH, lino H, Nakamura K, Serrato A, Oyama K (2008) Breakdown of the one-to-one rule in Mexican fig-wasp associations inferred by molecular phylogenetic analysis. Symbiosis 45:73-81

Sun XJ, Xiao JH, Cook JM, Feng G, Huang DW (2011) Comparisons of host mitochondrial, nuclear and endosymbiont bacterial genes reveal cryptic fig wasp species and the effects of Wolbachia on host mtDNA evolution and diversity. BMC Evol Biol 11:86

Sutton TL, DeGabriel JL, Riegler M, Cook JM (2017) Local coexistence and genetic isolation of three pollinator species on the same fig tree species. Heredity 118:486-490

Tamura K, Stecher G, Peterson D, Filipski A, Kumar S (2013) MEGA 6: molecular evolutionary genetics analysis version 6.0. Mol Biol Evol 30:2725-2729

Tzeng HY, Lu FY, Ou CH, Lu KC, Tseng LJ (2006) Pollinational-mutualism strategy of Ficus erecta var. beecheyana and Blastophaga nipponica in seasonal Guandaushi forest ecosystem, Taiwan. Bot Stud 47:307-318

Van Noort S, Compton SG (1996) Convergent evolution of Agaoninae and Sycoecinae (Agaonidae, Chalcidoidea) head shape in response to the constraints of host fig morphology. J Biogeogr 23:415-424

van Noort S, Ware AB, Compton SG (1989) Pollinator-specific volatile attractants released from the figs of Ficus burtt-davyi. S Afr J Sci 85:323-324

van Noort S, Wang R, Compton SG (2013) Fig wasps (Hymenoptera: Chalcidoidea: Agaonidae, Pteromalidae) associated with Asian fig trees (Ficus, Moraceae) in southern Africa: Asian followers and African colonists. Afr Invertebr 54:381-400

Wachi N, Kusumi J, Tzeng HY, Su ZH (2016) Genome wide sequence data suggest the possibility of pollinator sharing by host shift in dioecious figs (Moraceae, Ficus). Mol Ecol 25:5732-5746

Wang G, Cannon CH, Chen J (2016) Pollinator sharing and gene flow among closely related sympatric dioecious fig taxa. Proc R Soc Lond S B 283:20152963 
Ware AB, Compton SG (1992) Breakdown of pollinator specificity in an African fig tree. Biotropica 24:544-549

Wei ZD, Kobmoo N, Cruaud A, Kjellberg F (2014) Genetic structure and hybridization in the species group of Ficus auriculata: can closely related sympatric Ficus species retain their genetic identity while sharing pollinators? Mol Ecol 23:3538-3550

Weiblen GD (2004) Correlated evolution in fig pollination. Sys Biol 53:128-139

Wiebes JT (1979) Co-evolution of figs and their insect pollinators. Ann Rev Ecol Syst 10:1-12

Wiebes JT (1993) Agaonidae (Hymenoptera Chalcidoidea) and Ficus (Moraceae): fig wasps and their figs, XI (Blastophaga) s.I. Proc Kon Ned Akad Wet Ser C 96:347-367

Wilde BC, Rutherford S, van der Merwe M, Murray ML, Rossetto M (2020) First example of hybridization between two Australian figs (Moraceae). Aust Syst Bot 33:436-445

Yang DR, Peng YQ, Song QS, Zhang GM, Wang RW, Zhao TZ, Wang QY (2002) Pollination biology of Ficus hispida in the tropical rainforests of Xishuangbanna, China. Acta Bot Sin 44:519-526

Yang LY, Machado CA, Dang XD, Peng YQ, Yang DR, Zhang DY et al (2015) The incidence and pattern of co-pollinator diversification in dioecious and monoecious figs. Evolution 69:294-304

Yakushiji H, Morita T, Jikumaru S, Ikegami H, Azuma A, Koshita Y (2012) Interspecific hybridization of fig (Ficus carica L.) and Ficus erecta Thunb., a source of Ceratocystis canker resistance. Euphytica 183:39-47
Yu H, Zhao NX, Chen YZ, Deng Y, Yao JY, Ye HG (2006) Phenology and reproductive model of a common fig (Ficus hirta Vahl.) in Guangzhou. Bot Stud 47:435-441

Yu H, Compton SG (2012) Moving your sons to safety: galls containing male fig wasps expand into the centre of figs, away from enemies. PLoS ONE 7:e30833

Yu H, Liang D, Tian EW, Zheng LN, Kjellberg F (2018) Plant geographic phenotypic variation drives diversification in its associated community of a phytophagous insect and its parasitoids. BMC Evol Biol 18:134

Yu H, Tian EW, Zheng LN, Deng XX, Cheng YF, Chen LF et al (2019) Multiple parapatric pollinators have radiated across a continental fig tree displaying clinal genetic variation. Mol Ecol 28:2391-2405

Zhang T, Miao BG, Wang B, Peng YQ, Darwell CT (2019) Non-pollinating cheater wasps benefit from seasonally poor performance of the mutualistic pollinating wasps at the northern limit of the range of Ficus macrocarpa. Ecol Entomol 44:844-848

Zhang T, Jandér CK, Huang JF, Wang B, Zhao JB, Miao BG et al (2021) The evolution of parasitism from mutualism in wasps pollinating the fig, Ficus microcarpa, in Yunnan Province. China PNAS 118:e2021148118

Zhou ZH, Gilbert MG (2003) Moraceae Flora of China 5:21-73

\section{Publisher's Note}

Springer Nature remains neutral with regard to jurisdictional claims in published maps and institutional affiliations.

\section{Submit your manuscript to a SpringerOpen ${ }^{\circ}$ journal and benefit from:}

- Convenient online submission

- Rigorous peer review

- Open access: articles freely available online

- High visibility within the field

- Retaining the copyright to your article

Submit your next manuscript at $\boldsymbol{\nabla}$ springeropen.com 